\title{
Chapter 9 \\ Income Trajectories of Lone Parents After \\ Divorce: A View with Belgian Register Data
}

\author{
Dimitri Mortelmans and Christine Defever
}

\section{Introduction}

The rise in lone parenthood is one of the most striking symbols of the twenty-first transitions of family life in the Western world. At present, the classic married twoparent family is still regarded as the dominant family norm, although the statistical reality has surpassed the symbolic one. In a few decades, family forms will have such a huge diversity that no dominant, classic or modern family forms will be discerned. We will observe a multitude of family types (Pasteels et al. 2013). The rise of the Western welfare states and the shifts in values we observed during the past four decades started a huge turn in both the composition and the meaning of families. The theory of the Second Demographic Transition (SDT) sees a ideational shift as the driving force behind the changes in demographic behaviour (Lesthaeghe 1995, 2002; Van de Kaa 1994). First, a decline in the birth rates have decreased the size of today's families. Second, the type of relationships in which children are raised has changed. The dominant position of marriage is eroding and the new millennium sees a sharp increase in cohabitation throughout Europe. If people do marry, they marry at older ages (De Wachter 2013) as we observe with parenthood. Postponing parenthood is also often renunciating it leading to smaller families (Bulckens et al. 2007).

The transition this chapter is focusing on, is the rise in divorce and the subsequent increase in the number of lone parent families that often originates from that life course transition. Also this transition finds its origin in the ideational and economic shifts of recent history (Deboosere et al. 2011). Belgium is particularly suited to study lone parenthood since the rise in divorce has quadrupled in the past 30 years and is still increasing today (Corijn 2005; Mortelmans et al. 2011). When comparing

D. Mortelmans $(\varangle) \cdot C$. Defever

CLLS, Faculty of Social Sciences, University of Antwerp, Antwerp, Belgium

e-mail: dimitri.mortelmans@uantwerpen.be 
divorce figures, Belgium has one of the highest dissolution rates in the European Union. In 50 years, Belgium changed from a Catholic marriage-prone country to the most unstable marriage market (see also: Mortelmans 2013; Mortelmans et al. 2009b). Within the country, regional differences between Flanders and Wallonia are considerable whereby Flanders is slowly closing in on the highest divorce figure in the southern part of the country (Mortelmans et al. 2009a). We study Flanders partly because of the availability of data but also because Flanders has a unique combination of welfare measures and labour market policies that add to the aid of lone mothers to cope with their precarious (income) position. The longitudinal data of the CBSS (see methods section) also allow us to gain reliable insights in the income trajectories of lone parents. Income measures in surveys are always a source of concern and looking at income in small populations like lone parents is an even bigger challenge (Frick and Krell 2010).

In this chapter, we first elaborate on the evolution of lone parenthood in Belgium. We illustrate how this family type rose in importance during the last decades. Next we look at earlier studies that document the socio-economic position of lone parents. A third paragraph introduces the study of this chapter and more specifically the empirical definition(s) of lone parenthood. Before we come to the results and show the income trajectories of lone parents in Flanders, we first need to make clear how administrative data determine our scope. In our analyses, we adopt a life course perspective looking at lone parenthood in a longitudinal fashion: how do lone parents cope with their financial position and who succeeds in tackling the financial downturn after a relationship breakup?

\section{The Rise of Lone Parenthood in Belgium}

The number of lone parents has risen considerably. Several studies have made estimations of the number and evolution of this family type during the past decades. Differences in estimation are often due to differences in definitions or data available. Instead of choosing one single data source, we opt for presenting a multitude of estimations and perspectives in order to get a picture of the lone parenthood prevalence in Belgium and Flanders.

The most important household type in Belgium is the one-person household. The proportion of people living alone rose by 38\% between 1990 and 2007 (Lodewijckx 2008). In comparison, the share of married couples with children decreased with $20 \%$ and the share of non-married couples with children nearly quadrupled. The reason for the sharp increase in one-person households is the aging population of the country. Most of these single person households are widowed persons. Among the multiple-person households the share of couples (with children) is decreasing while the number of single parent households is sharply increasing (Lodewijckx 2001, 2004a, b). In Flanders, the number of parents raising children on their own increased from 146,800 in 1990 to 205,100 in 2007 (Lodewijckx 2008). When taking figures from the census 2011 (not completely comparable to the study of 
Lodewijckx), we observe 518,700 lone parent households in Flanders (a share of $9.3 \%$ of all households).

When looking at these figures from a child's perspective, we observe an increase from of 117,000 children living with one parent in 1990 to 193,000 children in 2007 (Lodewijckx 2008). Again, the census is more difficult to compare but in 2011 a total of 362,818 children (in Belgium) or a share of $19.4 \%$ of children under 15 are living in a single parent household (Swennen and Mortelmans 2015). We do need to take into account that these figures are momentary cross sections of the population. After a relational break-up, people often get new relationships. Not all single parents in the official statistics are without a partner. We estimated that in Belgium, eight out of ten divorcees will repartner, whether or not living together (Pasteels and Mortelmans 2013).

Lone parenthood is strongly gender determined. The vast majority of children living with one parent, are living with their mother. Valgaeren (2008) estimated that one quarter of the lone parent household were lone father households and three quarters were lone mothers. In the census of 2011, we find comparable figures: $21 \%$ versus $79 \%$. Despite the huge growth in lone parent families, the gender gap has not shifted. When looking at all mothers, the ONA observes huge differences according to the regions in Belgium. In the capital region of Brussels, nearly one third (28.17\%) of all women with children are heading a lone parent family. In Flanders only $13.65 \%$ is head of a lone parent family with $22.99 \%$ in Wallonia (Office national d'allocations familiales pour travailleurs salariés 2008). For fathers, the total percentage amounts only to $3.44 \%$ with again a higher share in Brussels and the lowest in Flanders.

Since the 2007 change in the Belgian divorce legislation, the share of coparenthood is sharply increasing. This is due to a new regulation that obliges judges to first investigate the possibility of co-parenthood. It is difficult to integrate this co-parenting in the figures of the prevalence of lone parenthood. Some indications can be found in the study of the National Service of Child Support of Workers (RKW). Between 2007 and 2011, the number of entitlements of child support in case of co-parenthood increased with $30.8 \%$. In 2011, 60.5\% of all divorced parents entitled to child support had a co-parenthood agreement (RKW 2011). The Divorce in Flanders study (Mortelmans et al. 2011) estimates the percentage of co-parenthood at $21.4 \%$. Also this study finds an increase over the years, due to a change in legislation. The shared co-parenthood has risen from $6.8 \%$ for divorces before 1995 to $27.1 \%$ in the period after 2006 (Sodermans et al. 2011).

\section{Income, Poverty and Lone Parenthood in the Life Course}

The sociology of the life course stresses temporal shifts in the lives of people. Often, cross sectional data are the only data available forcing us to one-time snapshots of families. The huge advantage of the registers is that we can observe the financial situation of lone parents over time. It allows us to see which strategies they use to 
keep up when the income position becomes difficult after a break-up. This process is a reaction with a temporal change and is termed a coping strategy in the literature. We define a coping strategy as 'a behavioural pattern of an actor to deal with problems, referring to the usual and institutionalized ways of feeling, thinking and acting in such situations' (Boeije and Nievaard 1995). When looking at the financial coping behaviour after a divorce, we discern two main coping mechanisms: finding a new partner and changing ones labour market behaviour as two ways that positively influence the financial well-being of an ex-spouse (de Regt et al. 2010, 2012; Jansen et al. 2009). We look at these two strategies from the perspective of a lone parent. We assume that also in these cases, a new (co-residing) partner or an increase in labour market participation will help in reducing the (sometimes) difficult reduction in financial position.

The register data in this study does not allow us to relate the gross income of lone parents to poverty lines (calculated on net incomes). But using the EU-Silc survey data, Van Lancker and colleagues were able to estimate the poverty risk of lone parents and compare it with other family types (Defever et al. 2013; Frans et al. 2014). Using the $60 \%$ of the median income, the Belgian poverty line of 2010 is at 12,005 Euro while the Flemish one is slightly higher (12,592 for a single person). The mean poverty risk in the country is $15.3 \%$ with huge regional differences between Wallonia (19.2\%) and Flanders (9.8\%). However, when comparing the poverty risk relative to the regional poverty line, the Flemish poverty risk (12.4\%) is closer to the one in Wallonia (15.3\%).

Van Lanker and colleagues show that the poverty risks in Flanders are highly dependent on the family type somebody is living in. Couples with children have the lowest poverty risk (5\%). Single persons have a considerable higher risk (14\%) but still lower than lone parents (19\%). When looking at the total population of people below the $60 \%$ median income, lone parents make up about $10 \%$. Even though the poverty risk among couples with children is lower, in population figures, they are $27 \%$ of the total population under the poverty line (Defever et al. 2013; Van Lancker et al. 2012).

One explanation for the increased risk in poverty is the low work intensity. By definition, a lone parent is the only potential breadwinner. In a couple the risk at poverty is different since one partner can be unemployed or absent from the labour market and still rely on the income of the second partner. Lone parents need to work in order to provide income to the household. Earlier studies have shown for Flanders that lone parents are lower educated, more unemployed or absent from the labour market (Cantillon et al. 2004; Mortelmans and Dewilde 2008; Valgaeren 2008). Also in Brussels and Wallonia, a lower work intensity has been observed (Observatoire Bruxellois de l'Emploi 2009; Office national d'allocations familiales pour travailleurs salariés 2008).

An important advantage of using register data is also the possibility to include the gender dimension in the discussion. Often, lone parents are underrepresented in surveys and men within this group are even more rare and invisible. The gender differences are visible both on the labour market and in the household. In general, Belgian women are less active on the labour market. The difference in employment 
rate between men and women decreases over time but still remains substantial. In 2012, almost $67 \%$ of the men (15-64 years) were working, compared to merely $57 \%$ of the women. On average, in 2013, a Belgian woman also earned $10 \%$ less per hour worked than a man. Due to a large share of part-time working women, the pay gap rises to $23 \%$ on an annual basis (Van Hove 2013). The issue of these inequalities becomes apparent when the relationship ends in a divorce or a break-up. Different longitudinal studies have shown that the financial situation of men is relatively stable or even ameliorates. For women, the evolution shows a negative trend in all studies (Andreß et al. 2006). In addition, their situation is also improving in a slow pace, taking a considerable number of years to overcome the financial consequences of divorce (Jansen et al. 2009).

\section{Belgian Divorce Legislation and Financial Consequences of Divorce}

When considering the income position and living conditions of lone parents, it is necessary to briefly show how people end up in this family form. Not that we will present the Belgian divorce legislation in extenso, but particularly the major law reform of 2007 is essential in the rise in lone parent but more specifically in the change in post-divorce material circumstances. The change in 2007 was probably the biggest reform since 1994 (first reform) and 1804 (original law on divorce).

The philosophy of the first divorce law was to protect the basic societal functions of the marriage (procreation, socialization and material welfare). The 2007 reform changed this philosophy by considering the marriage now as a private contract. Not a commercial private contract but a contract originating in love and decomposed when the love is gone. Whenever one of the partners considers the marriage as over, both partners are now given the opportunity to end the marriage with "no strings attached'. The law initiated the no-fault divorce and aimed for a quick divorce assuming this would lead to less conflict. Partners are given a 'right' to divorce and no longer need to prove that the other partner has made a mistake in the marriage (adultery for example).

But the divorce procedure was not only shortened, the consequences of divorce have also changed. Before the reform, the so-called innocent husband was entitled to alimony. With the introduction of the no-fault divorce, the rights to alimony also changed into a more universal right to alimony. The only exceptions to the universal right are serious situations like domestic violence whereby a partner can lose the right to alimony. But unlike the universal character of the access to alimony, the new divorce law introduced the time-based alimony payment. Alimony can only be paid for a period that not exceeds the length of the marriage itself. The previous principle of a life-long alimony right, was abandoned. Partners are incited to become active on the labour market and take care of their own income. This has huge implications for lone parents because not only their alimony-income is reduced in time, the new law also changed the definition of the access to the right which implied that the 
amounts due are lowered (Cuypers et al. 2008). The child support regulation has not been changed in 2007 but in the Child support objectification law of 2010. Child support can be determined by the judge or through a proposal of the both ex partners. The height of the child support can vary considerably with no standardized calculation methods available (Claessens and Mortelmans 2015).

Other changes that are relevant for this chapter is the change in co-parenthood. With the introduction of this law, a judge is now obliged to examine the possibility of a shared residence (co-parenthood) as the first option for the children's residence. The classic arrangement (only a weekend with one parent every 2 weeks) is still popular but the new law started a huge shift towards co-parenthood. As a consequence, children are more residing with both their mother and their father (often they have a week on-week off arrangement). In these cases, the number of lone parents rises but the amounts of child support among partners decreases since both parents take care of the children.

\section{Aims}

The focus of this chapter lies on the financial trajectory of lone parents after divorce. We aim to bring insights in the financial life course of lone parents by studying their income trajectories over time. The longitudinal character of the register data allows us to do so. Having a large data set, we also explicitly adopt a gender perspective on the finances by analyzing both lone mothers and lone fathers. This will increase our insights in the gender gap among lone parents. Since income trajectories are to a large extent influenced by the household composition, a third aim of this study is to gain insights in the household trajectory of ex-partner after divorce and specifically in the entry and exit of parents in the lone parenthood status.

Based on the theoretical considerations of the previous paragraphs, we come to the following hypotheses:

H1 Women have a higher chance of entering the lone parenthood state compared to men and they have more difficulties leaving the status.

H2 In general, divorced men experience less income loss after divorce compared to women.

H3 The income loss of lone parents will be bigger compared to single or repartnered ex-spouses and within one parent, differences will be larger for lone mothers, compared to lone fathers.

H4 Staying lone parent will have a more negative impact on the financial life course than making the transition to singlehood or a repartnered status. Again, differences will be larger for lone mothers, compared to lone fathers.

H5 For lone mothers, increasing their labour market status will be most beneficial to their post-divorce income trajectory. Unemployment and inactivity have the most detrimental effects on the post-divorce income. 


\section{Data and the Identification of Lone Parents}

In this study, we use the datawarehouse 'Labour market and social protection'. This datawarehouse is managed by the Crossroads Bank of Social Security $(\mathrm{CBSS})^{1}$ which clusters register data of social security agencies (see also: Mortelmans and Pasteels 2013). We obtained a random sample of persons living in Flanders and married or cohabiting on December 31, 2003 ( $\mathrm{T}-1)$, but no longer living in the same household on December 31, 2004 (T) (they have experienced a relational breakup or a bereavement during 2004) ${ }^{2}$ (Defever and Mortelmans 2011). The sample contains $25 \%$ of all divorced or widowed men and women in the year 2004. For our analyses, we will use only persons that have been divorced and are available to the labour market (18-59 year) in 2004. This entails a sample of 17.044 divorcees. These sample members were followed from $2003(\mathrm{~T}-1)$ until $2008(\mathrm{~T}+4)$. All results on sample members in 2005 concern the situation of persons who are divorced at 31 December 2005. Since we only have one demographic position for each year, the status of lone parents is clearly a snapshot in time.

For each household, we calculated the gross yearly income. This household income is composed of all income from labour and social security remittances of all members of the household, but without any taxes or social security payments. The amounts from labour, remittances and pensions are available in the CBSS database. The amounts for minimal income wages and child support were estimated from the data available. Child support was calculated with the number of children in the household, the year, ages of children, household composition and labour market participation of parents and children. Minimal wages were estimated based on the composition of the household of the person entitled to the minimal wage. Since the CBSS does not have any reliable income data (from labour) for self-employed people, no household income was calculated for families in which one of the members was self-employed (this is $19 \%$ of the sample of divorcees).

To make the incomes comparable between different household compositions and sizes, we use a modified OECD-scale (Hagenaars et al. 1994). A household income is weighted by the number of adults and the number of children living in the household. The head of the household has a weight of 1. Each additional adult older than 13 years has a weight of 0.5 and each child below 13 years receives 0.3 . A lone parent with three children will show a smaller household income in our analyses than a lone parent household with one child if the non-standardized income of both households is identical.

The CBSS data uses the LIPRO typology - developed by the Dutch Interdisciplinary Demographic Institute (NIDI). This typology contain seven individual household types (next to one so-called collective household) (Lodewijckx

\footnotetext{
${ }^{1}$ We wish to thank the Crossroads Bank of Social Security and more particular Chis Brijs for their cooperation in this research.

${ }^{2}$ For a divorce this means that the person was no longer married or co-residing with the partner on December 31, 2004 with the same partner they lived with on December 312003 but they can be living with a new partner.
} 
Table 9.1 Number and share of lone parents on December 31, 2004, according to the LIPRO and adapted definition, in absolute numbers and percentages

\begin{tabular}{l|r|r}
\hline & N & \multicolumn{1}{l}{$\%$} \\
\hline Total group of persons experiencing a divorce in 2004 & 17,044 & 100 \\
\hline Lone parents according to the LIPRO typology & 4,291 & 25 \\
\hline Lone parents according to the adapted definition & 3,474 & 20 \\
\hline Difference between both definitions & 817 & 5 \\
\hline Lone parents according to the LIPRO typology & 4,291 & 100 \\
\hline Reason drop-out: No own child or child older than 25 & 384 & 9 \\
\hline Reason drop-out: Child between 19 and 25 year with a labour income & 378 & 9 \\
\hline Reason drop-out: Undeterminable & 125 & 3
\end{tabular}

Source: Datawarehouse ‘labour market and social protection' - Crossroads bank of Social Security, own calculation

and Deboosere 2008). A single parent in the LIPRO typology is defined as " $a$ man or woman heading a household and not co-residing with a partner but co-residing with one or more (biological or step-)children" (Lodewijckx 2004a). This is a very broad definition because no limitations to age, civil status or potential income of the children is included. A single woman living together with her 40 year old divorced son is considered to be a single mother in this definition. Therefore, we define a lone parent in this chapter as a person heading a household alone with no partner and (biological or step)children that are younger than 18 year or younger than 25 when they do not have a labour income. Stated differently, we do not consider a household as a single parent household when: (1) there is a child older than 24 in the household, (2) a child between 18 and 25 having a labour income of its own, (3) a child younger than 18 that is not a biological, nor a step child of the reference person.

This definition is more strict than the definition of the LIPRO typology. Table 9.1 gives an overview of the households we lose from the CBSS when using this definition of lone parents. The percentages are based on the administrative data recorded at December 31, 2004.

According to the LIPRO typology, $25 \%$ of all persons experiencing a divorce in 2004 are heading a single parent household after the divorce. If we take our more limited definition, the percentage drops to $20 \%$. One significant reason for the drop is the labour income of children between 18 and 25 year (9\% of the lone parents according to the LIPRO definition). The same drop is discernible among the households with children older than 25 or with children that are not related to the single parent (again $9 \%$ of the lone parents according to the LIPRO definition). Only a small percentage (3\%) could not be unambiguously determined with the data that was available. We decided to consider these cases as non-sample members in our study.

The focus of our analyses are individual persons and not households. Therefore, we will discuss 'lone parents' (or single fathers and mothers) or 'heads of single parent household'. Persons living alone in a household - without partner or children in the household' will be termed 'singles'. If we consider 'repartnered persons', we refer to persons that have a new partner living in the household. The register data do not capture (romantic) relationships until somebody actually moves into the household. 
The analytical strategy will follow the hypotheses put forward in paragraph 5 . First, we look at the trajectories in household composition 1 year after divorce $(\mathrm{T}+1)$ and again 3 years later $(\mathrm{T}+4)$. In addition, survival curves will allow us to zoom in on the duration of lone parenthood over time. The second analysis concerns the gendered patterns in income after divorce. A first analysis will compare lone parents with other household types. All trajectories are described from the year before the divorce $(T-1)$ up until 4 years after the break-up $(T+4)$. The same analysis is repeated for those who start as lone parent in $\mathrm{T}$ and we look how differences in household composition at $\mathrm{T}+4$ influence the income trajectory. The final analysis looks at the position on the labour market. Since the lone parents have too little variation in their labour market trajectories, we only focus on lone mothers in this last analysis. Again, a dynamic comparison is made between $\mathrm{T}-1$ and $\mathrm{T}+4$. We look at income effects for women who do not changes their labour market position, and who decrease/increase their attachment to the labour market.

\section{Results}

\section{Partner Trajectories in Lone Parenthood}

In this study, we selected all divorces in 2004. As mentioned before, these persons were living together with their partner in 2003 but that partner has left the household at the end of 2004. In the study, we follow a subset of these divorces. Only those who are lone parent in 2004, are adopted in the empirical sample. One year later $(\mathrm{T}+1)$, we see that already one third of the lone fathers have changed their household position. Either the children $(12.8 \%)$ are no longer living with their father (presumably they are staying with the mother) or the lone father started living together with a new partner (14.6\%). For lone mothers, having no children anymore is rare $(1.8 \%)$. Women hardly see their children move into the fathers household. On the other hand, having a new partner in the household is much more common. About one fifth of the lone mothers $(17.4 \%)$ find a new partner within 1 year.

When observing the lone parents 4 years later, we see that less than half of the lone mothers $(45.9 \%)$ and only one third of the lone fathers $(31.4 \%)$ remain the single head of their household. Figure 9.1 illustrates this longitudinal pattern by means of survival curves for men and women and the hazard function. The survival function of men is lower than for women, indicating a quicker exit as lone parent than women. The hazard rate shows a decrease in the hazard of leaving the lone parent status until 2 years after the breakup. After 2 years the hazard of entering a new household type are increasing again.

In our register, women do not leave the lone partner status as easily as men. However, they seem both to find a new partner in about one third of the cases (see Table 9.2). The finding is not confirmed with survey data. For Flanders, the Divorce in Flanders study found a lower repartnering chance for women (Pasteels and Mortelmans 2013). Comparing with older research of de Graaf and Kalmijn (2003) 

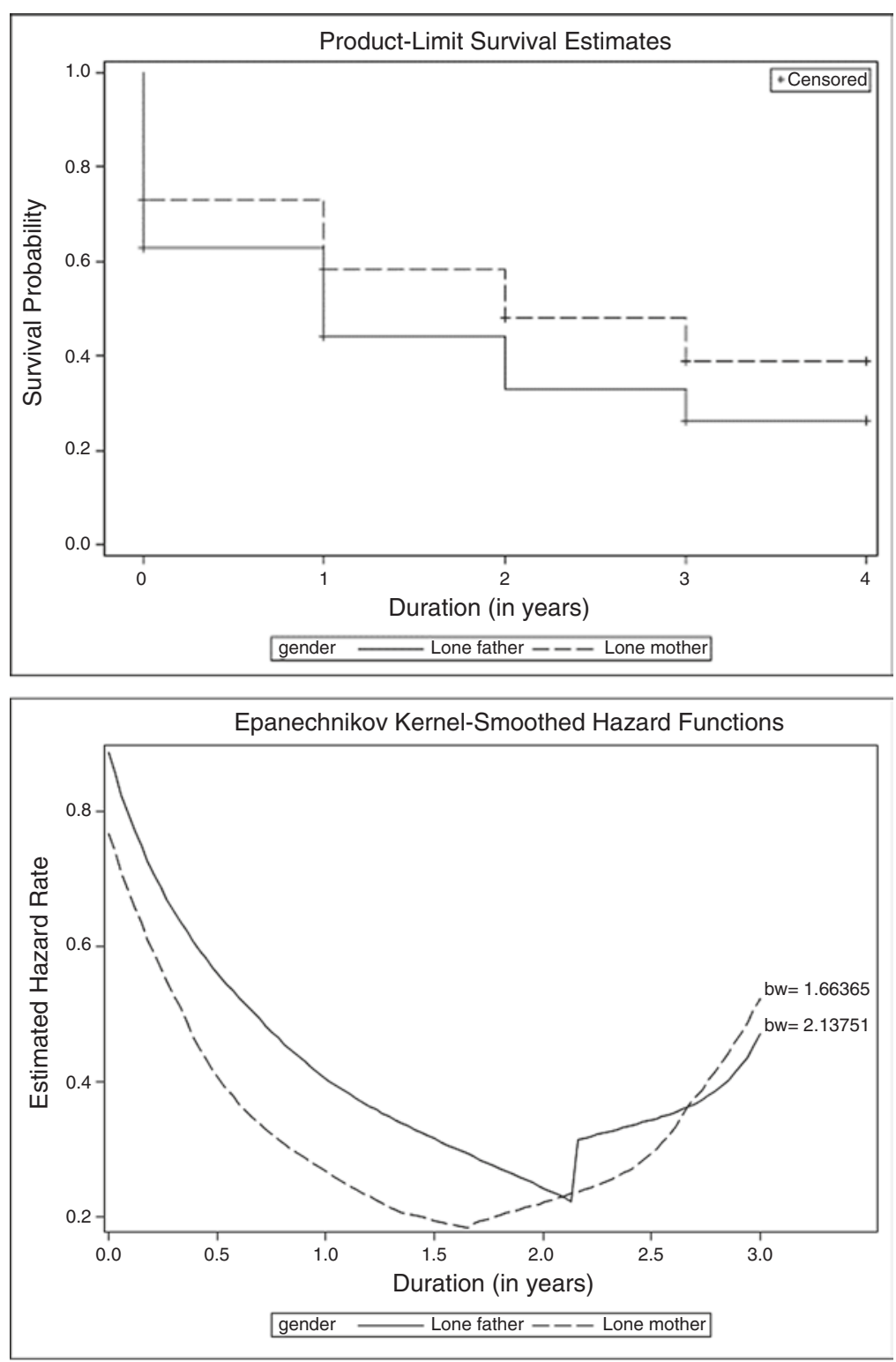

Fig. 9.1 Survival estimates and hazard function of lone parenthood by gender of the lone parent

the registers observe an acceleration of repartnering patterns. Both men and women repartner in a quicker pace than one or two decades ago. This might be contradictive to the observation that the number of lone parents is increasing but that is not necessary so. Despite the huge repartnering speed among lone parents, the influx of divorcees in the lone parenthood status has a net effect of increasing the total number of lone parent households. 
Table 9.2 Evolution of the size and proportion of household types after divorce among lone parents in 2004, to gender, in absolute numbers and relative \%, 2005-2008

\begin{tabular}{|c|c|c|c|c|c|}
\hline & \multirow[b]{2}{*}{ HHType } & \multicolumn{2}{|c|}{$T+1(2005)$} & \multicolumn{2}{|c|}{$T+4(2008)$} \\
\hline & & $\mathrm{N}$ & $\%$ & $\mathrm{~N}$ & $\%$ \\
\hline \multirow[t]{5}{*}{ Man } & Lone father & 417 & 62.9 & 205 & 31.4 \\
\hline & Single living father & 85 & 12.8 & 119 & 18.2 \\
\hline & Father with new partner & 97 & 14.6 & 227 & 34.8 \\
\hline & Living with parents & 3 & 0.5 & 8 & 1.2 \\
\hline & Different ${ }^{\mathrm{a}}$ & 61 & 9.2 & 94 & 14.4 \\
\hline Total (lone fathers in 2004) & & 663 & 100.0 & 653 & 100.0 \\
\hline \multirow[t]{5}{*}{ Woman } & Lone mother & 2,052 & 73.1 & 1,275 & 45.9 \\
\hline & Single living mother & 50 & 1.8 & 94 & 3.4 \\
\hline & Mother with new partner & 487 & 17.4 & 984 & 35.4 \\
\hline & Living with parents & 18 & 0.6 & 30 & 1.1 \\
\hline & Different $^{\mathrm{a}}$ & 200 & 7.1 & 396 & 14.3 \\
\hline Total (lone mothers in 2004) & & 2,807 & 100.0 & 2,779 & 100.0 \\
\hline
\end{tabular}

Source: CBSS Datawarehouse, own calculations

aThe category 'Different' brings together all persons that do not resort under one of the previous four categories. For example somebody who goes living with a friend, an older person who moves to a nursing home, a person who is single parent according to the LIPRO typology but not according to our definition (see above), etcetera

\section{Income Effects of Repartnering}

To compensate the loss of income, lone parents can either repartner or change their labour market participation (if possible). One can increase the number of hours, change employer, etc. Changing one's work can be driven by income motives but can also be an answer to a work-life conflict arising from the break-up.

Research has shown that not repartnering after divorce has the worst negative financial outcomes for women in the long run (Manting and Bouman 2006). Also Jansen et al. (2009) found that, for lone mothers, a new partner has more beneficial financial consequences than changing ones labour market hours. Also, working more hours is not possible in all situations. Geurts (2006) has shown that young single parents (under 30 years) have young children (under the age of 2.5 years $^{3}$ ). These children cannot (yet) go to school, making the combination between work and care difficult. Only when children are older than 6, the labour market participation of lone mothers equal or surpasses than of mothers with a co-residing partner. Also one's education and the history of labour participation plays an important role in the activation chances after the break-up (for an overview, see Valgaeren 2008).

Tables 9.3 and 9.4 give insight in the evolution of the post-divorce median yearly income trajectories according to partnership status. Table 9.3 gives a view from the start onwards. We follow those who started in T (December 31, 2004) as lone parents, single parents or co-residing parents and we follow these men and women for

\footnotetext{
${ }^{3}$ From the age of 2.5 onwards, children in Belgium are admitted to the official and free) kindergarten. That means that parents have better opportunities to combine work and care.
} 


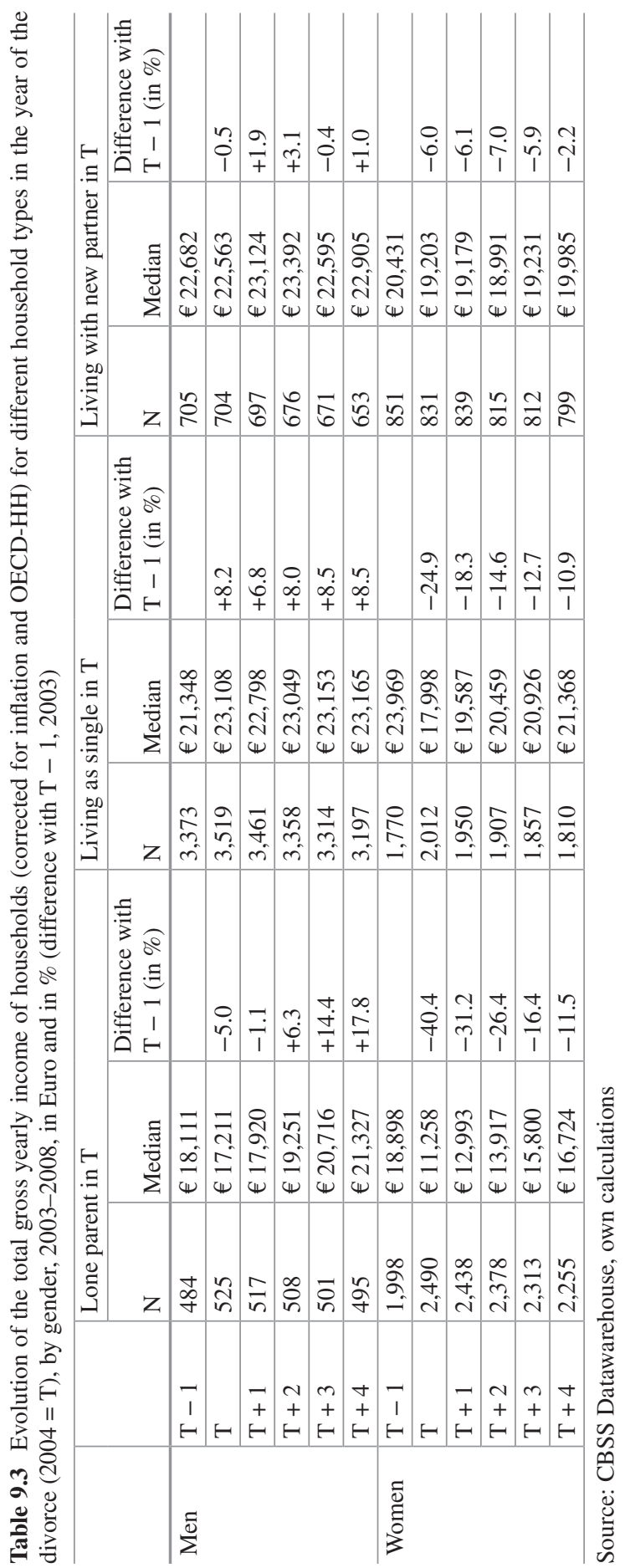




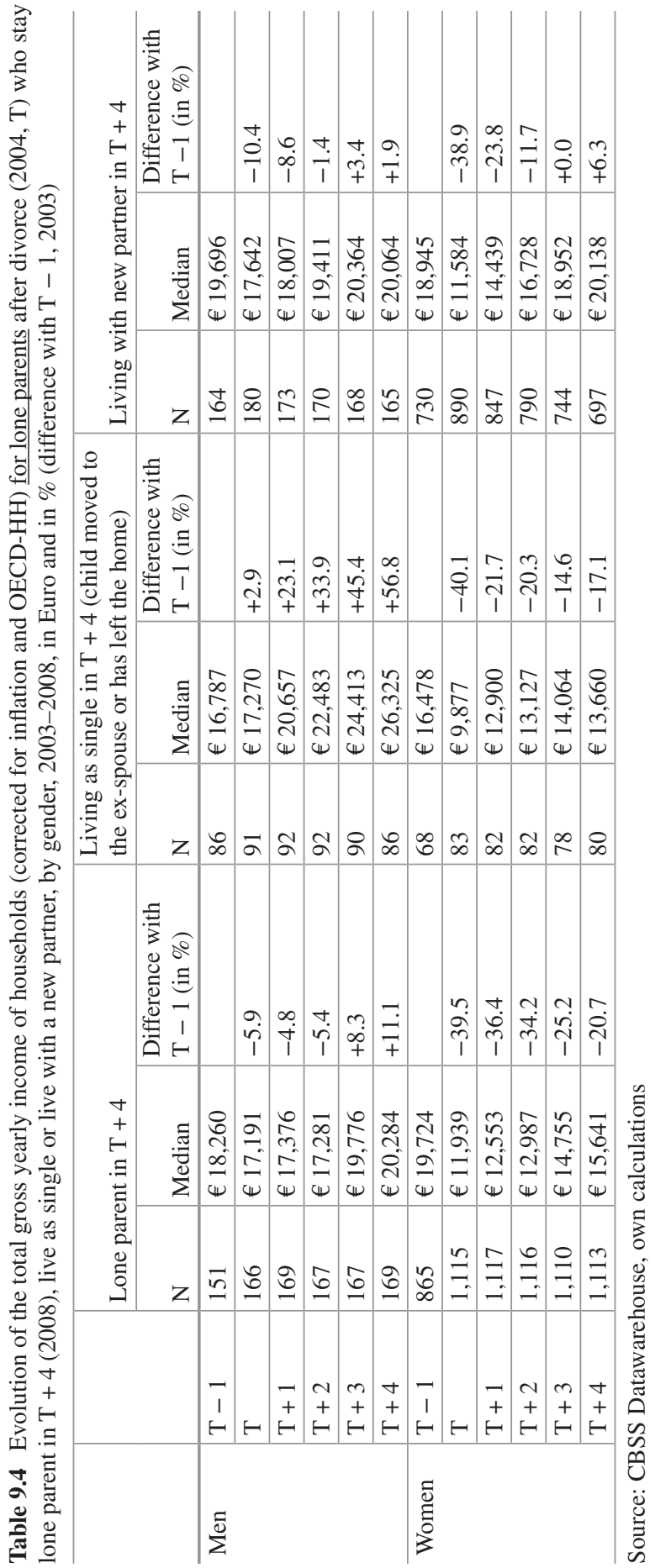


four consecutive years (independent from changes in this period). Table 9.4 on the other hand gives an overview of the evolution of income of men and women who started after divorce as a lone parent, single parent or co-residing parent and remained in that status for 4 years. From the numbers in the two tables, we can derive that stability in these statuses is rather scarce. Especially the lone parenthood status among men and the single status among both genders is scarce. The $\mathrm{N}$ becomes rather small in these cases but nevertheless, the income trajectories show quite interesting evolutions.

We start with Table 9.3 and look at the income loss after the transition ( $\mathrm{T}-1$ to $\mathrm{T}$ ). Everybody, except single fathers see their income decreasing. The differences however are substantial. Women, whether as lone parent or as single lose 40 or $25 \%$ respectively of their pre-divorce income. For lone father, the loss is as limited as mother who immediately repartner after divorce. Off course, these are median income evolutions. At the tails of the distribution losses are more substantial. Repartnering clearly is the most optimal pathway to recover from the initial income loss.

When we look at the evolution, 4 years later, we observe only minor changes for those households in which the divorcee started living with a new partner after the break. Also single fathers have a quite stable income trajectory during these 4 years. Single fathers see an increase in income compared to the pre-divorce situation, especially after 2 years. This is in line with the repartner patterns we have observed earlier. The situation of single women and lone mothers is more problematic. Even though the initial drop in income is compensated over the years, the income loss 4 years after the break still amounts to $10 \%$. Both regain income (by repartnering or increasing their labour market participation) but the loss is still present after 4 years.

When we look at the stable trajectories over 4 years (Table 9.4), we see similar trends: less income loss for men and more loss for lone parents. Even though we need to be careful due to the low numbers, the differences are much more outspoken than when we do not control for stability of the trajectory. When women remain lone parent for 4 years, they can only reduce their income loss to $-20.7 \%$ instead of $-11.5 \%$. For single women, the difference is almost the same: still $17.1 \%$ loss after 4 years instead of a loss of $10.9 \%$.

\section{Income Effects of Labour Market Participation}

Finding a new partner clearly makes a difference in the income trajectory of a lone parent. But as de Graaf and Kalmijn (2003) and Pasteels and Mortelmans (2013) showed, repartnering is more difficult in case of lone parents as the children makes them less attractive on the repartner market. In this paragraph, we look at the labour market attachment of lone parents. We limit our analyses to women. The reason behind this decision is straightforward: there is almost no variation in the male labour market trajectories. Nearly all men work in our sample and they all stay at work (full time) after the break.

In Table 9.5, we look at the labour market situation after 4 years for women who became lone parent after their divorce. We compare the situation at time T (2004) 
9 Income Trajectories of Lone Parents After Divorce: A View with Belgian Register...

Table 9.5 Evolution of the total gross yearly income for households (corrected for inflation and OECD-HH) for women who were lone parents in the year of divorce (T, 2004), by labour market evolution ( $\mathrm{T}-1$ compared to $\mathrm{T}+4$ ), in Euro and in \% (difference with $\mathrm{T}-1,2003$ )

\begin{tabular}{|c|c|c|c|c|c|}
\hline & & & $\mathrm{N}$ & Median & Difference with $\mathrm{T}-1$ (in $\%)$ \\
\hline \multirow[t]{16}{*}{ No changes } & \multirow{3}{*}{$\begin{array}{l}\text { Stay full time } \\
\text { working }\end{array}$} & $\mathrm{T}-1$ & 414 & $€ 25,812$ & \\
\hline & & $\mathrm{T}$ & 515 & $€ 18,237$ & -29.3 \\
\hline & & $\mathrm{T}+4$ & 476 & $€ 23,528$ & -8.8 \\
\hline & \multirow{3}{*}{$\begin{array}{l}\text { Stays part time } \\
\text { working }\end{array}$} & $\mathrm{T}-1$ & 180 & $€ 22,042$ & \\
\hline & & $\mathrm{T}$ & 221 & $€ 12,639$ & -42.7 \\
\hline & & $\mathrm{T}+4$ & 203 & $€ 17,166$ & -22.1 \\
\hline & \multirow{3}{*}{$\begin{array}{l}\text { Stays in } \\
\text { unemployment }\end{array}$} & $\mathrm{T}-1$ & 53 & $€ 10,578$ & \\
\hline & & $\mathrm{T}$ & 61 & $€ 7,224$ & -31.7 \\
\hline & & $\mathrm{T}+4$ & 61 & $€ 11,435$ & +8.1 \\
\hline & \multirow[t]{3}{*}{ Stays inactive } & $\mathrm{T}-1$ & 62 & $€ 10,797$ & \\
\hline & & $\mathrm{T}$ & 70 & $€ 6,429$ & -40.5 \\
\hline & & $\mathrm{T}+4$ & 67 & $€ 10,216$ & -5.4 \\
\hline & \multirow{4}{*}{$\begin{array}{l}\text { Stays in status } \\
\text { "other" }\end{array}$} & $\mathrm{T}-1$ & 253 & $€ 9,496$ & \\
\hline & & $\mathrm{T}$ & 319 & $€ 3,361$ & -64.6 \\
\hline & & $\mathrm{T}+4$ & 286 & $€ 5,911$ & -37.8 \\
\hline & & & $\mathrm{N}$ & Median & Difference with $\mathrm{T}-1$ (in $\%)$ \\
\hline \multirow{13}{*}{$\begin{array}{l}\text { Increase labour } \\
\text { participation }\end{array}$} & \multirow{3}{*}{$\begin{array}{l}\text { Increases labour } \\
\text { hours }\end{array}$} & $\mathrm{T}-1$ & 341 & $€ 20,484$ & \\
\hline & & $\mathrm{T}$ & 444 & $€ 12,629$ & $-38,3$ \\
\hline & & $\mathrm{T}+4$ & 412 & $€ 20,334$ & -0.7 \\
\hline & \multirow{3}{*}{$\begin{array}{l}\text { Unemployed to } \\
\text { employed }\end{array}$} & $\mathrm{T}-1$ & 89 & $€ 14,224$ & \\
\hline & & $\mathrm{T}$ & 100 & $€ 8,025$ & -43.6 \\
\hline & & $\mathrm{T}+4$ & 89 & $€ 15,426$ & +8.5 \\
\hline & \multirow{3}{*}{$\begin{array}{l}\text { Inactive to } \\
\text { employed }\end{array}$} & $\mathrm{T}-1$ & 74 & $€ 13,084$ & \\
\hline & & $\mathrm{T}$ & 87 & $€ 8,202$ & -37.3 \\
\hline & & $\mathrm{T}+4$ & 72 & $€ 15,263$ & +16.7 \\
\hline & \multirow{4}{*}{$\begin{array}{l}\text { "Other" to } \\
\text { employed }\end{array}$} & $\mathrm{T}-1$ & 486 & $€ 13,203$ & \\
\hline & & $\mathrm{T}$ & 637 & $€ 7,672$ & -41.9 \\
\hline & & $\mathrm{T}+4$ & 601 & $€ 14,942$ & 13.2 \\
\hline & & & $\mathrm{N}$ & Median & Difference with $\mathrm{T}-1$ (in $\%)$ \\
\hline \multirow{9}{*}{$\begin{array}{l}\text { Decrease labour } \\
\text { participation }\end{array}$} & \multirow{3}{*}{$\begin{array}{l}\text { Decreases } \\
\text { working hours }\end{array}$} & $\mathrm{T}-1$ & 234 & $€ 21,529$ & \\
\hline & & $\mathrm{T}$ & 280 & $€ 13,565$ & -37.0 \\
\hline & & $\mathrm{T}+4$ & 244 & $€ 17,750$ & -17.6 \\
\hline & \multirow{3}{*}{$\begin{array}{l}\text { From employed } \\
\text { to unemployed }\end{array}$} & $\mathrm{T}-1$ & 61 & $€ 16,618$ & \\
\hline & & $\mathrm{T}$ & 75 & $€ 8,573$ & -48.4 \\
\hline & & $\mathrm{T}+4$ & 78 & $€ 11,941$ & -28.1 \\
\hline & \multirow{3}{*}{$\begin{array}{l}\text { From employed } \\
\text { to inactive }\end{array}$} & $\mathrm{T}-1$ & 58 & $€ 16,189$ & \\
\hline & & $\mathrm{T}$ & 69 & $€ 7,810$ & -51.8 \\
\hline & & $\mathrm{T}+4$ & 62 & $€ 9,940$ & -38.6 \\
\hline
\end{tabular}

Source: CBSS Datawarehouse, own calculations 
with the position 4 years later (2008). In Table 9.5, we look at stability, increase in participation and decrease in participation at the labour market.

For all lone mothers, we see a decrease of their income after their divorce. In most of the cases, the decrease is around $40 \%$ as we mentioned earlier. Only in the case where women worked full time, the drop in income is clearly smaller in year T. When women do not change their activity on the labour market, their initial position keeps determining their income trajectory. As could be expected, a relative lower reduction in income is observed among lone mothers who remain in full time labour. Their median yearly income is also the highest of all women in this sub sample.

To our surprise, part time work did not have the protective effect we expected. In fact, staying out of the labour market (inactive or other) and especially unemployed lone mothers have a much more favourable income trajectory than the part time working women. Even though their income level is well above the unemployed or inactive women, their relative earnings are not restoring as well as the other women. Off course, the precariousness of the unemployed and the inactive women is much bigger as can be seen in their median yearly income. That level lies about one third or more lower than the income level of the part time working women.

When we look at the women who increase their labour market participation (ether or not from zero), the picture is consistent and clear: starting to work or working more decreases the income drop after divorce. In addition, women build up pension rights (Ponnet and Mortelmans 2008) which in the long term assures them a better position (at old age). The reverse is also expected: if the woman loses her job, her income position deteriorates significantly. The unemployment benefit protects women to a great extent. Especially women who are not entitled to an unemployment benefit (and who become inactive without any benefit) suffer severe income loss in a 4 year period and end up with a very low median income.

\section{Conclusion}

When we compare the income position of lone parents in Belgium with those in other countries, we find a relatively favourable situation. The poverty risk is rather limited in comparative perspective and Van Lancker et al. (2012) showed that it is also relatively stable over time. Nevertheless, within the context of the country, lone mothers show a higher than average poverty risk (Defever et al. 2013). Financial consequences of divorce are still highly gendered: women are more often the head of a lone parent household and their income drop is also significantly higher than that of lone fathers.

The poverty figures are only one side of the story. They show the instantaneous picture of who is above or below the poverty threshold. That is important for policy. In this chapter, we looked beyond this cross sectional approach and introduced a life course perspective. Looking at the dynamics behind lone parenthood enriches the view on lone parenthood by not only focusing on poverty and loss. The finding of 
an increased poverty risk does not help fight against the actual poverty when we do not have insights in the pathways of lone parents. Our point of departure is that people are not frozen targets after divorce but active agents. Even if a relational break-up lead to a severe income loss, people will start coping with the loss. Diminishing consumption levels is one option (out of scope of our study) but repartnering and work are two other coping mechanisms often used. Register data like those from the CBSS are excellently suited to look at dynamics on both the repartner market and the labour market.

A first finding concerns the status of lone parents. Men have the highest odds of leaving the lone parent status quickly (H1). Earlier, we found that men without children have high repartner chances. This study shows that even with children in the household, men repartner more quickly than women. Lone motherhood on the other hand is also not a stable state over the life course. After 4 years, more than half of the women who became lone mother after divorce, have found a partner (or became single because the children left the household).

In line with previous studies (Andreß et al. 2006; Jansen et al. 2009) we also find general post-divorce differences in income favourable for men and negative for women (H2). Within the group of divorcees, it is the group of lone parents and more specifically lone mothers who pay the financial price of the breakup (H3).

Finding a new partner turns out to be a successful strategy for lone mothers in terms of financial well-being (H4). For men, the new partner does not outweigh the single status in terms of finances. Especially because new partners often bring along new children which further increases the costs in the new constellated household. On the other hand, studies have shown that new partners have beneficial effects on the mental and physical health of divorced men (Bracke et al. 2010; Symoens et al. 2013). In the long run, new partners may protect men from an early entry in formal care provisions or emotional loneliness at old age.

The dynamics of the labour market are studied in a different chapter in this volume (see Struffolino and Mortelmans, Chap. 12, in this volume). This chapter focussed on the financial outcomes of changes on the labour market. For men, these dynamics and therefore also the consequences are nearly absent since they predominantly work full time and stay in that status during our observation window. For women, changes in the activity status do lead to better financial outcomes. Increasing ones labour market participation is the most successful strategy but this implies that the circumstances at home allow such an increase or in case of non-employment that the lone mother succeeds in finding an appropriate job (H5). The results on women who decrease their labour market attachment could reveal a double reality. On the one hand, this might be a deliberate strategy to cope with the work-life conflict lone mothers are confronted with. In that case, the strategy is deliberately chosen and the loss of the financial means can be a calculated risk in order to reconcile both life domains. On the other hand, the work-life conflict may also be the cause of the decrease. Women might lose their job or might be forced to reduce their working hours.

Looking at the prevalence and the dynamics of lone parent families, it is clear that this household type needs to stay a concern for policy makers. Even though the 
divorce trend is slowly stabilizing, the size of the group of lone parents is considerable and its size will not likely decrease in the coming decade. Earlier longitudinal analyses have shown that the first 6-7 years are difficult for most divorcees (Jansen et al. 2009). There is not only the loss of a partner and (often) one additional income. There is also the cost of the divorce itself: lawyers, moving, tax on buying out a house, new household furniture. A policy that wants to help in this transition needs to be careful for what we have called the "win for life" principle 4 (Cuypers et al. 2008). This provoking term asked attention for the simultaneous character of the problematic "shock effect" in the life course that is caused by a divorce. As our results show, many lone parents succeed in coping with the situation (even though they do not live generously). Policies that want to intervene after divorce need to start with the temporality of the break in the life course and try to attenuate the excrescences of the breakup.

We see two possible pathways. First, policies can enable lone parents (and especially lone mothers) to keep or increase their labour market participation. A sufficient supply of child care and a flexible arrangement in terms of opening hours is crucial in the combination of work and care after divorce. Second, financial interventions are possible to keep lone parents out of poverty during the first (and most difficult) years. This might be done through (temporary) increased child allowances. In Scandinavia, we see traces of this kind of policy showing a successful decrease of poverty among lone parent families (Defever et al. 2013).

The financial situation of lone parents shows an example of how a life course policy can be created. Allowances are thereby limited in time and specifically targeted to risks groups with the purpose of overcoming temporary shocks in the life course due to transitions (life a relational break-up). In that respect, we do not need to see these shocks as mere negative transitions. This study was able to show new insights by using large scale register data. Unfortunately, the absence of the educational level in the analyses hampered our analyses. Future studies with registers could replicate this study and document the way to which education mediates the financial trajectories of lone parents.

Acknowledgements This paper benefited from the support of the Swiss National Centre of Competence in Research LIVES - Overcoming Vulnerability: Life Course Perspectives, which is financed by the Swiss National Science Foundation (Grant number: 51NF40-160590).

\footnotetext{
4 "Win for life" refers to a product of the Belgian National Lottery. The first prize is a fixed income of 1000 Euro for the rest of the winner's life. It was used in a context where policy foresees a lifelong payment from the ex-spouse or the government to support the poorest partner after divorce.
} 


\section{References}

Andreß, H.-J., Borgloh, B., Bröckel, M., Giesselmann, M., \& Hummelstein, D. (2006). The economic consequences of partnership dissolution - A comparative analysis of panel studies from Belgium, Germany, Great Britain, Italy, and Sweden. European Sociological Review, 22(5), 533-560. Retrieved from http://esr.oxfordjournals.org/cgi/content/abstract/22/5/533.

Boeije, H. R., \& Nievaard, A. C. (1995). Strategieën en perspectieven van verzorgenden in het verpleeghuis. Tijdschrift voor Sociologie, 16(4), 345-361.

Bracke, P. F., Colman, E., Symoens, S. A., \& Van Praag, L. (2010). Divorce, divorce rates, and professional care seeking for mental health problems in Europe: A cross-sectional populationbased study. BMC Public Health, 10(1), 224.

Bulckens, R., Mortelmans, D., Casman, M. T., \& Simaÿs, C. (2007). Families in beweging. Een gezinsbeleid op maat? Brussel: Editions Luc Pire.

Cantillon, B., Verbist, G., \& De Maesschalck, V. (2004). De sociaal-economische positie van eenoudergezinnen. Over.Werk Tijdschrift van het Steunpunt WSE, 14(1-2), 139-143. Retrieved from http://www.steunpuntwerk.be/system/files/overwerk_2004_1-2_29.pdf.

Claessens, E., \& Mortelmans, D. (2015, September 18). Objectifying child support outcomes. An analysis of Belgian child support determination using fiscal data. Paper presented at the European Divorce Research Conference, Vilnius.

Corijn, M. (2005). Huwen, uit de echt scheiden en hertrouwen in België en in het Vlaamse gewest. CBGS Werkdocumenten, 2005(5), 98.

Cuypers, D., Mortelmans, D., \& Torfs, N. (Eds.). (2008). Echtscheiding: werkelijk win for life ? De sociologische en juridische gevolgen van het echtscheidingsrecht voor risicogroepen. Brugge: Die Keure.

de Graaf, P. M., \& Kalmijn, M. (2003). Alternative routes in the remarriage market: Competingrisk analyses of union formation after divorce. Social Forces, 81(4), 1459-1496. https://doi. org/10.1353/sof.2003.0052.

de Regt, S., Marynissen, T., \& Mortelmans, D. (2010). Omgaan met financiële gevolgen van een relatiebreuk: een latent groeimiddel bij gescheiden en ex-samenwonende vrouwen. Tijdschrift voor Sociologie, 31(2), 136-150.

de Regt, S., Mortelmans, D., \& Marynissen, T. (2012). Financial consequences of relationship dissolution: A longitudinal comparison of formerly married and unmarried cohabiting men and women. Sociology, 47(1), 90-108. https://doi.org/10.1177/0038038512453793.

De Wachter, D. (2013). Postponement or renouncement? A longitudinal analysis of new patterns of family formation using the 1991 and 2001 census. Brussel: Vrije Universiteit Brussel \& Universiteit Antwerpen.

Deboosere, P., Mortelmans, D., \& Marquet, J. (2011). Gezin: opvattingen over relaties, gezin, gender en familiale solidariteit. In K. Abts, K. Dobbelaere, \& L. Voyé (Eds.), Nieuwe tijden, nieuwe mensen. Belgen over arbeid, gezin, ethiek, religie en politiek (pp. 23-70). Leuven: Lannoo Campus.

Defever, C., \& Mortelmans, D. (2011). De socio-economische positie van vrouwen en mannen na de transities echtscheiding en verweduwing : een longitudinale studie op de kruispuntbank sociale zekerheid. Antwerpen: Steunpunt Gelijkekansenbeleid.

Defever, C., Van Lancker, W., Mortelmans, D., \& Cantillon, B. (2013). De inkomenspositie van alleenstaande ouders. In M. Callens (Ed.), Sociale Staat van Vlaanderen 2013 (pp. 93-136). Brussel: Studiedienst van de Vlaamse Gemeenschap.

Frans, D., Van Mechelen, N., \& Van Lancker, W. (2014). Een structurele aanpak van de verarming van eeenoudergezinnen in de federatie Wallonië-Brussel. Brussels: LKoning Boudewijstichting.

Frick, J. R., \& Krell, K. (2010). Measuring income in household panel surveys for Germany: A comparison of EU-SILC and SOEP. SOEP papers on Multidisciplinary Panel Data Research 265, Berlin: DIW.

Geurts, K. (2006). De arbeidsmarktpositie van alleenstaande ouders. Nieuwe bevindingen uit het Datawarehouse Arbeidsmarkt en Sociale Bescherming. Leuven: Steunpunt Werkgelegenheid, Arbeid en Vorming. 
Hagenaars, A., De Vos, K., \& Zaïdi, M. A. (1994). Poverty statistics in the late 1980s: Research based on micro data. Luxembourg: Office for official publications of the European Communities.

Jansen, M., Mortelmans, D., \& Snoeckx, L. (2009). Repartnering and (re-) employment: Strategies to cope with the economic consequences of partnership dissolution. Journal of Marriage and the Family, 71(5), 1271-1293. https://doi.org/10.1111/j.1741-3737.2009.00668.x.

Lesthaeghe, R. (1995). The second demographic transition in Western countries: An interpretation. In K. M. Oppenheim \& A.-M. Jensen (Eds.), Gender and family change in industrialized countries (pp. 17-62). Oxford: Clarendon Press.

Lesthaeghe, R. (Ed.). (2002). Meaning and choice: Value orientations and life course decisions. The Hague: NIDI.

Lodewijckx, E. (2001). Alleenstaande moeders en vaders in het Vlaams Gewest op 31/12/1996. Bijdragen onderzoek -Huishoudens. Retrieved from http://aps.vlaanderen.be/cbgs/repository/ eenouder.pdf.

Lodewijckx, E. (2004a). Alleenstaande ouders. In detail bekeken. Bijdragen onderzoek -Huishoudens. Retrieved from http://aps.vlaanderen.be/cbgs/repository/EL_Alleenstaande_ ouders.pdf.

Lodewijckx, E. (2004b). Types van huishoudens: veranderingen tussen 1991 en 2003. Bijdragen onderzoek, Huishoudens. Retrieved from http://aps.vlaanderen.be/cbgs/repository/typesvanhuishoudens_veranderingentssn90en03.pdf.

Lodewijckx, E. (2008). Veranderende leefvormen in het Vlaamse Gewest, 1990-2007 (en 2011). Een analyse uit het Rijksregister. SVR-rapport, 2008(3), 70.

Lodewijckx, E., \& Deboosere, P. (2008). Lipro: Een classificatie van huishoudens. SVR-Technisch rapport, 2.

Manting, D., \& Bouman, A. M. (2006). Short- and long-term economic consequences of the dissolution of marital and consensual unions. The example of the Netherlands. European Sociological Review, 22(4), 413-429. https://doi.org/10.1093/esr/jc1005.

Mortelmans, D. (2013). Belgium. In R. E. Emery (Ed.), Cultural sociology of divorce: An encyclopedia (pp. 127-130). Thousand Oaks: Sage.

Mortelmans, D., \& Dewilde, C. (2008). De economische gevolgen van echtscheiding: armoederisico's en copingstrategieën. In J. Vranken, G. Campaert, K. Deboyser, C. Dewilde, \& D. Dierckx (Eds.), Armoede en sociale uitsluiting. Jaarboek 2008 (pp. 199-219). Leuven: Acco.

Mortelmans, D., \& Pasteels, I. (2013). Using register data in the social sciences. SAGE Cases in Methodology. doi:https://doi.org/10.4135/978144627305013497458

Mortelmans, D., Snoeckx, L., \& Dronkers, J. (2009a). Cross-regional divorce risks in Belgium: Culture or legislative system? Journal of Divorce \& Remarriage, 50(8), 1-22.

Mortelmans, D., Snoeckx, L., \& Raeymaeckers, P. (2009b). Belgium: Economic hardship despite elaborate childcare and leave time programmes. In H.-J. Andress \& D. Hummelsheim (Eds.), When marriage ends. Economic and social consequences of partnership dissolution (pp. 78-97). Cheltenham: Edward Elgar.

Mortelmans, D., Pasteels, I., Bracke, P., Matthijs, K., Van Bavel, J., \& Van Peer, C. (2011). Scheiding in Vlaanderen. Leuven: Acco.

Observatoire Bruxellois de l'Emploi. (2009). Situation des familles monoparentales face à l'emploi et au chômage en region de Bruxelles-Capitale. Retrieved from http://www.actiris. be/marchemp/tabid/242/language/fr-BE/mctl/5/idPub/68/Description-publication.aspx

Office national d'allocations familiales pour travailleurs salariés. (2008). Les familles monoparentales en Belgique. Focus, 2008(2), 1-44.

Pasteels, I., \& Mortelmans, D. (2013). Gescheiden... en dan? Herpartneren in Vlaanderen anno 2010. Relaties en Nieuwe Gezinnen, 3(3), 1-66.

Pasteels, I., Lodewijckx, E., \& Mortelmans, D. (2013). Gezinstransities bij volwassenen. In C. Van Peer \& M. Corijn (Eds.), Gezinstransities in Vlaanderen (pp. In press). Brussel: Studiedienst van de Vlaamse Regering.

Ponnet, K., \& Mortelmans, D. (2008). Het armoederisico bij weduwen: verweduwing als levensloopgebeurtenis. In J. Vranken (Ed.), Armoede en sociale uitsluiting: jaarboek (pp. 241260). Leuven: Acco. 
RKW. (2011). Maatschappelijke veranderingen - De rijke diversiteit aan rechthebbenden. Jaar 2011 Publicaties. Brussel: RKW.

Sodermans, A. K., Vanassche, S., \& Matthijs, K. (2011). Gedeelde kinderen en plusouders: de verblijfsregeling en de gezinssituatie na scheiding. In D. Mortelmans, I. Pasteels, P. Bracke, K. Matthijs, J. Van Bavel, \& C. Van Peer (Eds.), Scheiding in Vlaanderen (pp. 133-151). Leuven: Acco.

Swennen, F., \& Mortelmans, D. (2015). National Report: Belgium. Brussels: CEFL.

Symoens, S., Bastaits, K., Mortelmans, D., \& Bracke, P. (2013). Breaking up, breaking hearts? Characteristics of the divorce process and wellbeing after divorce. Journal of Divorce \& Remarriage, 54(3), 177-196. https://doi.org/10.1080/10502556.2013.773792.

Valgaeren, E. (2008). De loopbanen en loopbaankansen van alleenstaande ouders. Retrieved from http://www.steunpuntgelijkekansen.be/wpcontent/uploads/II.1-De-loopbanen-enloopbaankansen-van-alleenstaande-ouders.pdf

Van de Kaa, D. J. (1994). The second demographic transition revisited: Theories and expectations. In H. Beets, H. van den Brekel, R. Cliquet, G. Dooghe, \& J. De Jong Gierveld (Eds.), Population and family in the low countries 1993: Late fertility and other current issues (pp. 81-126). Amsterdam: Swets and Zeitlinger.

Van Hove, H. (2013). The gender pay Gap in Belgium. In Report 2013. Brussels: Institute for the Equality of Women and Men.

Van Lancker, W., Ghysels, J., \& Cantillon, B. (2012). De impact van kinderbijslagen op het armoederisico van alleenstaande moeders: België in vergelijkend perspectief. Belgisch Tijdschrift voor Sociale Zekerheid, 54(2), 335-362.

Dimitri Mortelmans is Full Professor of Sociology at the Faculty of Political and Social Sciences of the University of Antwerp, Belgium. He teaches qualitative research methods, applied multivariate statistics and advanced topics in family sociology, life-course sociology and demography. He is head of the Centre for Longitudinal and Life Course Studies (CLLS). His research concentrates on family sociology and sociology of labour. He has published on divorce, new constituted families, gendered labour careers and work-life balance. He is also the main author of the Step in Statistics book series of which six volumes have been published (in Dutch). On qualitative methodology, he published the Handbook of Qualitative Research Methods and Qualitative Analysis with Nvivo.

Christine Defever holds a Master's degree in Sociology. She works as junior researcher in the Centre for Longitudinal and Life Course Studies (CLLS). She published a Gender Monitor for the Flemish Government and is currently researching lone parenthood and the transition to adulthood.

Open Access This chapter is licensed under the terms of the Creative Commons Attribution 4.0 International License (http://creativecommons.org/licenses/by/4.0/), which permits use, sharing, adaptation, distribution and reproduction in any medium or format, as long as you give appropriate credit to the original author(s) and the source, provide a link to the Creative Commons license and indicate if changes were made.

The images or other third party material in this chapter are included in the chapter's Creative Commons license, unless indicated otherwise in a credit line to the material. If material is not included in the chapter's Creative Commons license and your intended use is not permitted by statutory regulation or exceeds the permitted use, you will need to obtain permission directly from the copyright holder.

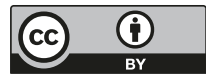

